\title{
Briefing: Atterberg limits and peat
}

Brendan C. O'Kelly PhD, FTCD, CEnv CEng MICE

Associate Professor, Department of Civil, Structural and Environmental

Engineering, Trinity College Dublin, Dublin, Ireland

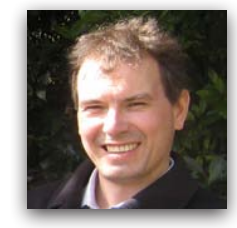

The Atterberg limits are the most common tests specified by practising geotechnical engineers worldwide. These tests, which have physical meaning for fine-grained mineral soils, are regularly specified for peat and other highly organic soils despite fundamental issues regarding their appropriateness for such materials. These issues are explored in this briefing from which it is concluded that Atterberg limit concepts are inappropriate for peat and are unlikely to meaningfully correlate with mechanical (strength) behaviour. In assessing likely engineering behaviour of peat, a more useful suite of index tests is natural water content, organic content, fibre content and degree of humification. For correlations with strength and compressibility parameters, Dutch organic soil practice has found that water content and bulk density are usually sufficient.

\section{Introduction}

The liquid limit (LL) and plastic limit (PL), collectively known as the Atterberg limits, have physical meaning for fine-grained mineral soils and are the most common tests specified by practising geotechnical engineers worldwide. They are used to classify soils and are also correlated with many fundamental soil parameters used in design and construction projects. The Casagrande (percussion cup) LL describes the water content at which the solid particles lose contact with one another and the soil begins to behave as a liquid material and flow. The standard PL (thread rolling) defines the limit of soil workability, that is, the ductilebrittle transition. Peat deposits are formed by the accumulation of the fragmented remains of dead plant vegetation, at various stages of humification, under waterlogged conditions. There are fundamental issues regarding the application of Atterberg limit concepts to peat (and other highly organic soils), and these are explored in this briefing.

\section{Fabric and microstructural differences for peat}

Peat material is significantly different from fine-grained mineral soil in fabric and microstructure. Peat can range from fibrous (showing little or no humification) to amorphous (completely humified), amorphous referring to an indeterminate unorganised structure. Unlike pure frictional contacts in remoulded mineral soils, connectivity between the fibres in fibrous peat is provided by cellular connections and fibre entanglement (Landva et al., 1986; O'Kelly, 2015) (see Figure 1). In other words, shear failure in fibrous peat also involves tearing of entangled fibres and cellular connections. In peats with low humification, the peat fibres have relatively high tensile stiffness and strength as well as providing conduits for preferential flow of water.

Furthermore, the organic solids in peat are themselves porous (see Figure 1), flexible and compressible in nature, leading to the two-level structure of micro- and macropores (Berry and Poskitt, 1972). Micropores are provided by the open cellular structure within fibrous peat particles and contain 'intracellular water'. For instance, in the case of the Canadian Sphagnum peat, which has insignificant to very slight humification investigated by Landva and Pheeney (1980), about two-thirds of the total water in the peat was contained in micropores. Macropores comprise the interstitial space between the solid particles and contain interparticle water, which can drain under gravity. Water content can also be influenced by the high cation-exchange ability of the peat-forming plants, which governs the thickness and rigidity of the adsorbed water layer (Hobbs, 1986). This produces stronger adsorption complex and greater interparticle adherence, which contributes to higher values of water content and also increases LL for fibrous peat (Hobbs, 1986). For fen peat, Hobbs (1986) found that the LL declines with increasing humification because, as the plant tissues are broken down, so the strength of the adsorption complexes on the cell walls are steadily weakened. The relative proportions and total quantity of macropore, micropore and adsorbed waters in peat material depend mainly on the morphology, structure and degree of humification of the constituent plants (Farrell, 2012; Hobbs, 1986). Because of this large water-holding capacity, peat material has extremely high natural water content, generally in the range 500-2000\% (Farrell, 2012). 


\section{Offprint provided courtesy of www.icevirtuallibrary.com Author copy for personal use, not for distribution}

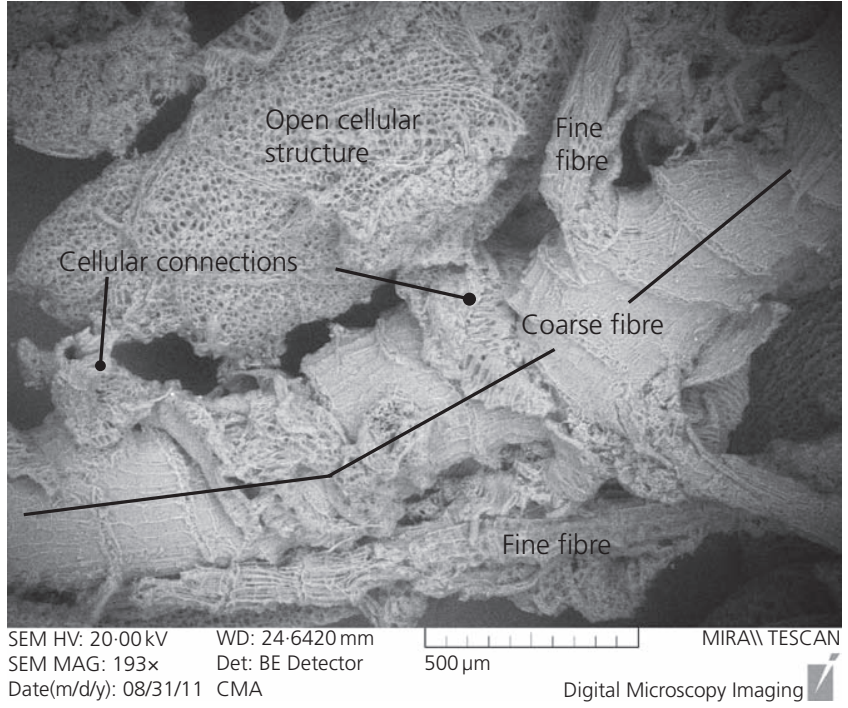

Figure 1. Scanning electron micrograph of slightly humified Sphagnum peat fibres from Clara raised bog, Ireland (adopted from O'Kelly BC and Zhang L (2013) Consolidated-drained triaxial compression testing of peat. Geotechnical Testing Journa/ 36(3))

\section{Experience of Atterberg limit testing of peat}

In practice and research work, Atterberg limit tests are regularly performed on peat and other organic soils, although there are conflicting viewpoints in the literature on the value and significance of such testing. In performing the Casagrande LL test, Skempton and Petley (1970) reported no special difficulties for clayey peats and peats having a high or moderately high degree of humification (i.e. H6 to H9 on the von Post scale; see Landva and Pheeney, 1980; H1 referring to material that has undergone no humification and H10 to material that is completely humified (amorphous)). For less humified peats $(<\mathrm{H} 5)$, they found that the LL test became less satisfactory and it was considered to be of questionable significance for slightly humified (H3) peat. Farrell (2012) reported that the LL test can generally be performed on peats having a degree of humification greater than von Post H3. According to Landva et al. (1983), peats and peaty organic soils containing significant amounts of fibrous material are not likely to have well-defined Casagrande LLs. Long and Boylan (2012) reported that due to the effect of the fibres, it is not possible to determine the LL of peat using either the Casagrande cup or fall-cone method. The application of the LL test to other fibrous organic soils (e.g. paper mill sludge (Moo-Young and Zimmie, 1996), sewage sludge/biosolids (O'Kelly, 2013), and water-treatment residue material (O'Kelly, 2014)) has also been questioned. For example, Moo-Young and Zimmie (1996) reported that paper fibres and tissues in paper mill sludge caused problems when cutting the groove in performing the Casagrande LL test.

For peats, Landva et al. (1983) reported that, as a general rule, PL values should be reported only on the basis of the specimens displaying behaviour normally associated with fine-grained mineral soil throughout the PL test. According to Farrell (2012), the PL can only be determined for peats having some clay particles: very small clay content may not produce reliable results (Whitlow, 2001). Skempton and Petley (1970) reported that the PL cannot be readily determined for peat, even at high humification (for $<\mathrm{H} 5$, the PL could not be measured satisfactorily), and furthermore, the test was undoubtedly subject to operator-dependent variations. Peat produces a very weak, spongy or fibrous thread, which may be difficult to form, and if the peat thread can be moulded into the required cylindrical shape (initial dimensions), the soil thread often fails in attempting to roll it out (Adon et al., 2013) following the standardised procedure. In this context, because the peat thread cannot be rolled out to a certain standard diameter (i.e. $3.0 \mathrm{~mm}$ (BSI, 1990) or $3.2 \mathrm{~mm}$ (ASTM, 2010)), the material is reported as non-plastic. However, in practice, remoulded peat has high plasticity (plastic range) and also high dry strength. Experimental data presented for a pseudo-fibrous peat (O'Kelly and Zhang, 2013; Zhang and O'Kelly, 2014) and amorphous organic clay (O'Kelly, 2014) having organic contents of $98.6 \%$ and $57 \%$, respectively, demonstrated that the bulk materials could be easily remoulded by hand pressure at water contents well below measured PLs. This would indicate that the measured plastic ranges were notional and, furthermore, calculated liquidity index values would not be reliable indicators of material consistency. It was postulated in the study for the peat material investigated that the overprediction in water content value for the limit of workability was due to scale effects in the PL test related to fibrous particles present. Following from the above, it would appear that the PL test is generally not appropriate for peat, especially raised bog (moss) peats, which typically have insignificant mineral content $(<\sim 2 \%)$. In his comprehensive treatise on the subject, Hobbs (1986) concluded that the plasticity properties of peat, where obtainable, do not meaningfully (significantly) correlate with mechanical behaviour, and consequently, there is little point in performing PL determinations for peat. In relation to the LL, Hobbs (1986) demonstrated that LL can be a useful indicator of morphology (initial cation-exchange ability depends on the type of plant detritus) and degree of humification, for example, $\mathrm{LL}=$ $800-1500 \%$ for bog peats compared with $200-600 \%$ for fen peats. However, peat classification systems (e.g. von Post) can arguably fulfil this role with equal if not better effect. He also reported that for a given morphology (bog or fen peat), LL correlates with the compression index parameter since it is also a function of the cationexchange ability (implied in the LL).

\section{Discussion}

The physics and chemistry of the peat, the chemistry and $\mathrm{pH}$ of the water in the peat and nature of its organic matrix exert important influences on deduced Atterberg limit values (Asadi et al., 2011; Hobbs, 1986; Yang and Dykes, 2006). The chemistry and $\mathrm{pH}$ of any water added to the peat material in producing the homogeneous paste for Atterberg limit testing can also significantly influence the LL value deduced (Asadi et al., 2011; Hanrahan et al., 1967; Yang and Dykes, 2006). In preparing the test material, differences between the standard method (which was developed for fine-grained mineral soil) and alternative approaches adopted by some operators can produce test materials having significantly different fabrics and structures 


\section{Offprint provided courtesy of www.icevirtuallibrary.com Author copy for personal use, not for distribution}

and hence distinctly different mechanical and hydraulic properties, especially for less humified peats. Hence, measured Atterberg limit values can be strongly dependent on the sample preparation method adopted, particularly for fibrous peat. Removal of larger fibres and pieces of woody matter from fibrous peat (as allowed by the British Standard (BSI, 1990)) is unlikely to be consistent between different operators. Furthermore, according to Yang and Dykes (2006), there is no stated method that prescribes how a homogeneous paste can be obtained from the remaining peat material (e.g. mixing using a broad-bladed knife was adopted by Skempton and Petley (1970); domestic liquidisers have been used in other instances (Hobbs, 1986; O'Kelly and Zhang, 2013)). The prepared samples will, nevertheless, usually include particles of fragmented coarse fibres and/or woody matter, thereby contributing a small component to the test material having powerful adsorption properties (Hobbs, 1986), unrepresentative of the intact fibres in the original peat. Furthermore, mechanical breakdown of the organic solids' cellular structure causes the release of micropore water to the macropores. In the case of the amorphous organic clay studied by O'Kelly (2014), it was argued that quick-undrained mechanical behaviour (Atterberg limits and saturated remoulded undrained strength for the present discussion) is defined by the amount of interparticle water. This supposition is supported by Adon et al. (2013), who reported that the PL of peat was determined by its content of interparticle water. In other words, the content of intracellular water would have no significant bearing on undrained strength mobilised for dynamic (LL) or quick undrained (rapid cycles of stress applied in PL) tests. Water content determinations are, however, based on the total water which is evaporated by oven-drying.

In view of the above, what is invariably compromised by the disparity in sample preparation techniques employed for peat by different workers is the ability to meaningfully compare the results obtained from different studies. On a more fundamental level, the relevance of Atterberg limit values measured for peat must be questioned: what practical engineering meaning does testing of these (significantly) altered materials have for the original peat material? How can the measured Atterberg limits be related to the original (undisturbed) peat material? For the PL, an aspect that may merit investigation is the determination of PL based on crumbling at larger thread diameters ( $>3 \mathrm{~mm}$ ), in which case the effect of the maximum particle size potentially diminishes. According to the British Standard (BSI: BS1377, 1990), Atterberg limit testing of mineral soil is performed on material passing the $425 \mu \mathrm{m}$ sieve, giving a minimum specimen (thread) diameter/maximum particle size ratio for the PL test of $3 \cdot 0 / 0 \cdot 425 \approx 7 \cdot 1$. However, Prakash et al. (2009) and Haigh et al. (2013) have reported that, for a variety of mineral soils, there is no statistically significant trend of varying water content with thread diameter (2-6 $\mathrm{mm}$ range investigated) at failure.

\section{Suitable index tests for peat engineering correlations}

One consensus recommended for all organic soils is that instead of Atterberg limit tests, the natural water content, organic content, fibre content and degree of humification tests are routinely performed alongside investigations of strength, compressibility, hydraulic conductivity or other engineering properties (Edil and Wang, 2000). This suite of tests, as one consensus, is viewed as the equivalent of performing Atterberg limit tests for mineral soils, but without giving a measure of the plastic range. Over decades of usage, correlations have emerged between the values of the index properties and the values of directly useful design parameters for peat deposits. Organic content (from loss on ignition tests) has the useful relationship with the specific gravity of solids (see Skempton and Petley, 1970), which can be used to estimate the bulk density (unit weight). Fibre content (tested in accordance with ASTM (2013), due to a lack of an equivalent British Standard) provides a useful measure of peat composition and an indicator of potential tensile strength. In general, water content increases and bulk density decreases with increasing fibre content (Edil and Wang, 2000). The degree of humification (generally measured according to the von Post scale of H1 to H10) provides an indication of likely engineering properties; for example, shear strength and permeability typically reduce with increasing humification, although more humified peats are generally less compressible and also less prone to further consolidation compared with fibrous peats (O’Kelly and Pichan, 2013).

Another consensus has developed in Dutch organic soil practice, where it is recognised that the mainstays of correlations with strength and compressibility parameters are water content and bulk density; these are usually sufficing (den Haan and Feddema, 2013). Bulk density reflects organic content, with lower bulk densities associated with higher organic contents.

Other properties that may be of value in characterising peat are linear shrinkage and, particularly, if concrete design is a consideration, soil pH/acidity. Boylan et al. (2008) reported that linear shrinkage determined from intact peat samples seems to provide an indication of changes in humification level.

Furthermore, morphology is an important consideration and must be reflected in the peat description and classification and, in turn, must be included in the interpretation of engineering parameter values. A description of the in situ (undisturbed) peat is also most beneficial.

\section{Use of digital imaging methods}

The concepts of soil description and the approach to soil micromorphology have changed somewhat over the years with the new techniques developed to describe them (Zainorabidin et al., 2010). Digital imaging methods provide numerous opportunities for clearer identification of the peat morphology and the structure of the peat fabric, allowing more appropriate description and classification of the peat material and a better understanding of its structure and behaviour. For instance, peat morphologic characterisation by scanning electron microscopy has frequently been described in the literature (e.g. Landva and Pheeney, 1980; Kalaitzidis and Christanis, 2003). Peat humification can be visually traced, observing the peat 


\section{Offprint provided courtesy of www.icevirtuallibrary.com Author copy for personal use, not for distribution}

structure and morphological and structural changes occurring in the remains of the peat-forming plants. Zainorabidin et al. (2010) have reported the application of image analysis using Picasa and analySIS software to identify and quantify the presence of fibres in peat for classification purposes. However, despite the structure of peat, in its various aspects, affecting the engineering behaviour, there has been virtually no research reported that correlates different structural types with physical and engineering properties (Huat et al., 2014).

\section{Summary}

The use of Atterberg limits for peat and other organic soils is a carry-over from Soil Mechanics. Despite being regularly specified in practice and research work, Atterberg limits generally do not have physical meaning for peat material, especially for more fibrous peat. Furthermore, the general consensus in the geotechnical literature is that Atterberg limits do not meaningfully (significantly) correlate with mechanical/strength behaviour of peat. Despite remoulded peat material having high plasticity, peat threads generally cannot be rolled out to $3 \mathrm{~mm}$ diameter in the standard PL test. Measured Atterberg limits are often strongly dependent on the sample preparation method adopted, which itself is subject to operatordependent variations, particularly for less humified peat. As a result, measured plastic ranges are notional and hence calculated liquidity index values are not reliable indicators of material consistency. In assessing likely engineering behaviour of peat, a more useful suite of index tests is natural water content, organic content, fibre content and degree of humification. For correlations with strength and compressibility parameters, Dutch organic soil practice has found that water content and bulk density are usually sufficient.

\section{REFERENCES}

Adon R, Yasufuku N, Ishikura R and Wijeyesekera D (2013) New technique assessment of plastic limit of soft clay particularly peat soils. Memoirs of the Faculty of Engineering, Kyushu University (Fukuoka, Japan) 73(1): 47-55.

Asadi A, Huat BBK, Hanafi MM, Mohamed TA and Shariatmadari N (2011) Chemico-geomechanical sensitivities of tropical peat to pore fluid $\mathrm{pH}$ related to controlling electrokinetic environment. Journal of the Chinese Institute of Engineers 34(4): 481-487.

ASTM (2010) D4318-10e1: Standard test methods for liquid limit, plastic limit, and plasticity index of soils. ASTM International, West Conshohocken, PA, USA.

ASTM (2013) D1997-13: Standard test method for laboratory determination of the fiber content of peat samples by dry mass. ASTM International, West Conshohocken, PA, USA.

Berry PL and Poskitt TJ (1972) The consolidation of peat. Géotechnique 22(1): 27-52, http://dx.doi.org/10.1680/ geot.1972.22.1.27.

Boylan N, Jennings P and Long M (2008) Peat slope failure in Ireland. Quarterly Journal of Engineering Geology and Hydrogeology 41(1): 93-108.

BSI (1990) BS1377: Part 2. Methods of test for soils for civil engineering purposes (Classification tests). BSI, London, UK. den Haan E and Feddema A (2013) Deformation and strength of embankments on soft Dutch soil. Proceedings of the Institution of Civil Engineers - Geotechnical Engineering 166(3): 239-252, http://dx.doi.org/10.1680/geng.9.00086.

Edil TB and Wang X (2000) Shear strength and $\mathrm{K}_{0}$ of peats and organic soils. In Geotechnics of High Water Content Materials (Edil TB and Fox PJ (eds)). American Society for Testing and Materials, West Conshohocken, PA, USA, ASTM STP 1374, pp. 209-225.

Farrell ER (2012) Chapter 35 - Organics/peat soils. In ICE Manual of Geotechnical Engineering: Volume 1, Geotechnical Engineering Principles, Problematic Soils and Site Investigation (Burland J, Chapman T, Skinner $\mathrm{H}$ and Brown M (eds)). ICE Publishing, London, UK, pp. 463-479.

Haigh SK, Vardanega PJ and Bolton MD (2013) The plastic limit of clays. Géotechnique 63(6): 435-440.

Hanrahan ET, Dunne JM and Sodha VG (1967) Shear strength of peat. Proceedings of the Geotechnical Conference, Oslo, Norway, vol. 1, pp. 193-198.

Hobbs NB (1986) Mire morphology and the properties and behaviour of some British and foreign peats. Quarterly Journal of Engineering Geology 19(1): 7-80.

Huat BBK, Prasad A, Asadi A and Kazemian S (2014) Geotechnics of Organic Soils and Peat. CRC Press, Boca Raton, FL, USA.

Kalaitzidis S and Christanis K (2003) Scanning electron microscope studies of the Philippi peat (NE Greece): initial aspects. International Journal of Coal Geology 54(1): 69-77.

Landva AO and Pheeney PE (1980) Peat fabric and structure. Canadian Geotechnical Journal 17(3): 416-435.

Landva AO, Korpijaakko EO and Pheeney PE (1983) Geotechnical classification of peats and organic soils. In Testing of Peats and Organic Soils (Jarrett PM (ed.)). American Society for Testing and Materials, West Conshohocken, PA, USA, ASTM STP 820, pp. 37-51.

Landva AO, Pheeney PE, La Rochelle P and Briaud JL (1986) Structures on peatland - geotechnical investigations. In Proceedings Advances in Peatlands Engineering, Ottawa, Canada. National Research Council of Canada, Ottawa, ON, Canada, pp. 31-52.

Long M and Boylan N (2012) In situ testing of peat - a review and update on recent developments. Geotechnical Engineering Journal of the Southeast Asian Geotechnical Society 43(4): $41-55$.

Moo-Young HK and Zimmie TF (1996) Geotechnical properties of paper mill sludges for use in landfill covers. Journal of Geotechnical Engineering ASCE 122(9): 768-776.

O'Kelly BC (2013) Undrained shear strength-water content relationship for sewage sludge. Proceedings of the Institution of Civil Engineers - Geotechnical Engineering 166(6): 576-588, http://dx.doi.org/10.1680/geng.11.00016.

O'Kelly BC (2014) Characterisation and undrained strength of amorphous clay. Proceedings of the Institution of Civil Engineers - Geotechnical Engineering 167(3): 311-320, http://dx.doi.org/10.1680/geng.11.00025. 
O'Kelly BC (2015) Effective stress strength testing of peat. Proceedings of the Institution of Civil Engineers Environmental Geotechnics 2(1): 33-44, http://dx.doi. org/10.1680/envgeo.13.00112.

O'Kelly BC and Pichan SP (2013) Effects of decomposition on the compressibility of fibrous peat - A review. Geomechanics and Geoengineering 8(4): 286-296.

O'Kelly BC and Zhang L (2013) Consolidated-drained triaxial compression testing of peat. Geotechnical Testing Journal 36(3): 310-321.

Prakash K, Sridharan A and Prasanna HS (2009) A note on the determination of plastic limit of fine-grained soils. Geotechnical Testing Journal 32(4): 372-375.

Skempton AW and Petley DJ (1970) Ignition loss and other properties of peats and clays from Avonmouth, King's Lynn and Cranberry Moss. Géotechnique 20(4): 343-356, http:// dx.doi.org/10.1680/geot.1970.20.4.343.

Whitlow R (2001) Basic Soil Mechanics, 4th edn. Prentice Hall, Harlow, UK.

Yang J and Dykes AP (2006) The liquid limit of peat and its application to the understanding of Irish blanket bog failures. Landslides 3(3): 205-216.

Zainorabidin A, Wijeyesekera DC and Jayaratne R (2010) Fabric of peat soils using image analysis. In Proceedings of the Fifth Annual Conference on Advances in Computing and Technology. University of East London, London, UK, pp. 38-44.

Zhang L and O'Kelly BC (2014) The principle of effective stress and triaxial compression testing of peat. Proceedings of the Institution of Civil Engineers - Geotechnical Engineering 167(1): 40-50, http://dx.doi.org/10.1680/geng.12.00038.

\section{HOW CAN YOU CONTRIBUTE?}

To discuss this paper, please submit up to 500 words to theeditor at journals@ice.org.uk. Your contribution will be forwarded to the author(s) for a reply and, if considered appropriate by the editorial board, it will be published as a discussion in a future issue of the journal. 